\title{
Anti-inflammatory activity of an ethanolic Caesalpinia sappan extract in human chondrocytes and macrophages
}

\author{
Shengqian $Q$ Wu $\mathbf{u}^{\mathrm{a}, \mathrm{b}}$, Miguel Otero ${ }^{\mathrm{c}}$, Frank M Ungera, Mary B Goldring ${ }^{\mathrm{c}}$, Ampai \\ Phrutivorapongkul ${ }^{\mathrm{d}}$, Catharina $\mathrm{Chiari}^{\mathrm{e}}$, Alexander Kolb ${ }^{\mathrm{e}}$, Helmut Viernstein ${ }^{\mathrm{a}}$, and Stefan \\ Toegel ${ }^{\mathrm{a}, \mathrm{c}, \mathrm{e},{ }^{,}}$
}

aDepartment of Pharmaceutical Technology and Biopharmaceutics, University of Vienna, 1090 Vienna, Austria bepartment of Pharmacology and Toxicology, University of Vienna, 1090 Vienna, Austria 'Laboratory of Cartilage Biology, Research Division, Hospital for Special Surgery, Weill Cornell Medical College, New York, USA dDepartment of Pharmaceutical Sciences, Faculty of Pharmacy, Chiang Mai University, Chiang Mai, Thailand eDepartment of Orthopedics, Medical University Vienna, 1090 Vienna, Austria

\section{Abstract}

Aim of the study-Caesalpinia sappan is a common remedy in Traditional Chinese Medicine and possesses diverse biological activities including anti-inflammatory properties. Osteoarthritis $(\mathrm{OA})$ is a degenerative joint disease with an inflammatory component that drives the degradation of cartilage extracellular matrix. In order to provide a scientific basis for the applicability of Caesalpinia sappan in arthritic diseases, the present study aimed to assess the effects of an ethanolic Caesalpinia sappan extract (CSE) on human chondrocytes and macrophages.

\begin{abstract}
Materials and Methods-Primary human chondrocytes were isolated from cartilage specimens of OA patients. Primary cells, SW1353 chondrocytes and THP-1 macrophages were serum-starved and pretreated with different concentrations of CSE prior to stimulation with $10 \mathrm{ng} / \mathrm{ml}$ of interleukin-1beta (IL-1ß) or lipopolysaccharide (LPS). Following viability tests, nitric oxide (NO) and tumor necrosis factor-alpha (TNF- $\alpha$ ) were evaluated by Griess assay and ELISA, respectively. Using validated real-time PCR assays, mRNA levels of IL-1 $\beta$, TNF- $\alpha$, inducible nitric oxide synthase (iNOS), and cyclooxygenase-2 (COX-2) were quantified. SW1353 cells were cotransfected with a COX-2 luciferase reporter plasmid and nuclear factor-kappa-B (NF-kB) p50 and p65 expression vectors in the presence or absence of CSE.

Results-CSE dose-dependently inhibited the expression of pro-inflammatory cytokines IL-1ß and TNF- $\alpha$ in IL-1ß-stimulated chondrocytes and LPS-stimulated THP-1 macrophages. CSE further suppressed the synthesis of NO in primary OA chondrocytes by blocking iNOS mRNA expression. The inhibition of COX-2 transcription was found to be related with the CSE inhibition of the p65/p50-driven transactivation of the COX-2 promoter.
\end{abstract}

Conclusions-The present report is first to demonstrate the anti-inflammatory activity of CSE in an in vitro cell model of joint inflammation. CSE can effectively abrogate the IL-1ß-induced

(C) 2011 Elsevier Ireland Ltd. All rights reserved.

"Corresponding author Stefan Toegel, Department of Orthopedics, Medical University Vienna, Waehringer Guertel 18-20, A-1090 Vienna, AUSTRIA, Tel: 0043140400 7653, Fax: 0043140400 7641, stefan.toegel@meduniwien.ac.at.

Publisher's Disclaimer: This is a PDF file of an unedited manuscript that has been accepted for publication. As a service to our customers we are providing this early version of the manuscript. The manuscript will undergo copyediting, typesetting, and review of the resulting proof before it is published in its final citable form. Please note that during the production process errors may be discovered which could affect the content, and all legal disclaimers that apply to the journal pertain. 
over-expression of inflammatory mediators at the transcriptional level in human chondrocytes and macrophages, most likely by inhibiting NF- $\mathrm{BB}$ (p65/p50) signaling. Blockade of IL-1ß-induced $\mathrm{NF}-\kappa \mathrm{B}$ signaling and its downstream pro-inflammatory targets by CSE may be beneficial for reducing cartilage breakdown in arthritis.

\section{Keywords}

osteoarthritis; inflammation; chondrocytes; Caesalpinia sappan; cytokine; COX-2

\section{Introduction}

Osteoarthritis (OA) ranks among the major causes of physical disability of elderly patients, thus representing a critical factor in health economics. In contrast to rheumatoid arthritis, $\mathrm{OA}$ is conventionally not considered a classical inflammatory arthropathy, but thought to develop from chronic overuse or injury of the joint. However, evidence has accumulated that, besides mechanical and genetic factors, inflammatory processes within joint tissues contribute to the OA onset and progression. Chondrocytes, the unique cell component of articular cartilage, are embedded in a highly organized extracellular matrix (ECM), comprising collagen type II fibrils and proteoglycans, which confer to the cartilage structural rigidity and protective resiliency (Goldring and Marcu, 2009). In response to mechanical or biochemical stress, chondrocytes overexpress pro-inflammatory mediators such as interleukin-1beta (IL-1ß) and tumor necrosis factor-alpha (TNF- $\alpha$ ) that will, in an autocrine/ paracrine manner, stimulate their own production and induce the expression of matrixdegrading proteinases, including matrix metalloproteinases (MMPs) and a disintegrin and metalloproteinase with thrombospondin motifs (ADAMTS) (Goldring and Goldring, 2007; Bonnet and Walsh, 2005). Recently, it has been demonstrated that mediators such as prostaglandin $\mathrm{E}_{2}\left(\mathrm{PGE}_{2}\right)$ (Gosset et al., 2010) or nitric oxide (NO) (Tsuruda et al., 2004) play key roles in the induction of MMPs in an inflammatory context. In addition to the chondrocytes, macrophages that have infiltrated the OA synovium contribute to inflammation and matrix degradation in OA tissues (Benito et al., 2005; Bodenson et al., 2006). Therefore, inflammatory mediators represent potential targets for OA disease modification.

The mechanism of cartilage degradation in OA is known to be a multifactorial process. However, standard pharmacological interventions, such as the use of nonsteroidal antiinflammatory drugs (NSAIDs), often act in a monomodal way that is frequently associated with significant adverse effects (Fendrick and Greenberg, 2009). Although considerable progress has been made in the development of novel strategies, such as the use of direct MMP inhibitors, no clinically effective inhibitor exists to date. Thus, novel, safe and effective anti-inflammatory agents are demanded for the therapy of arthritic diseases. Nutraceuticals and phytopharmaceuticals that usually contain a range of active compounds targeting multiple pathways could provide an alternative to conventional treatment of OA (Clutterbuck et al., 2009). A comprehensive review on current nutraceuticals for the management of OA has been published elsewhere (Ameye and Chee, 2009).

Sappan Lignum, the heartwood of Caesalpinia sappan L. (Leguminosae), is the source of a natural red dye. In traditional Chinese medicine, Sappan wood has sweet, salty, and neutral characteristics, and is associated with the heart, liver and spleen meridians. Traditionally, it is applied as an aqueous decoction and prescribed to invigorate the blood system, promote menstruation, reduce pain and swelling (Chinese Pharmacopoeia, 2010). Additionally, Sappan wood has been medicinally recommended due to its astringent or diuretic properties, as well as for certain skin diseases (Sireeratawong et al., 2010). Recently, it has also been listed in the 15th edition of the Japanese Pharmacopoeia (Japanese Pharmacopoeia, 2006). 
Different extracts and active compounds isolated from Sappan lignum have been reported to possess diverse biological activities including antioxidative (Budami et al., 2003), antiinflammtory (Jeong et al., 2008), antibacterial (Xu and Lee, 2004) and anticonvulsive (Baek et al., 2000) effects. Brazilin, the major compound of Sappan Lignum, was reported to have anti-inflammatory (Hikino et al., 1977, Washiyama et al., 2009), antibacterial (Batubara et al., 2010), and antihepatotoxic effects (You et al., 2005). In addition, numerous other compounds from Sappan Lignum such as prostosappanins A-E or sappanchalcone have also been shown to display some of the different biological activities (Liu et al., 2009). To our knowledge, however, Caesalpinia sappan has not been evaluated in the context of $\mathrm{OA}$, and the effects of Caesalpinia sappan derived isolates on OA chondrocytes and synovial macrophages are unknown.

The present study, therefore, aimed to elucidate the anti-inflammatory activity of an ethanolic Caesalpinia sappan extract (CSE) in lipopolysaccharide (LPS)-stimulated human macrophages and IL-1ß-stimulated human chondrocytes. Particular focus was on the inhibition of gene expression of proinflammatory factors such as IL- $1 \beta$ and TNF- $\alpha$, and on the interference with $\mathrm{NO}$ production and NF- $\mathrm{KB}$-mediated $\mathrm{COX}-2$ promoter activation.

\section{Materials and Methods}

\subsection{Plant material and extraction}

The heartwoods of Caesalpinia sappan were collected in June 2006 in San-Pa-Thong district, Chiang Mai province, Thailand, and identified by comparison with the voucher specimen (No. 87-1631) at the Herbarium Section, Northern Research Center for Medicinal Plants, Faculty of Pharmacy, Chiang Mai University, Thailand. Powdered heartwood (30 g) was extracted with $95 \%$ ethanol $(350 \mathrm{ml})$ for $24 \mathrm{~h}$ using a Soxhlet apparatus and the resulting extract was concentrated under vacuum to yield a solid extract $(5.5 \mathrm{~g})$.

\subsection{Characterization of the extract}

Four batches of CSE were characterized by HPLC (ICS-3000, Dionex, USA) with a Nucleodur C-18 column (Macherey-Nagel, D) and a PDA-100 detector (Dionex) set at 280 $\mathrm{nm}$. The eluent system consisted of a 45 min gradient program from $10 \%$ to $100 \%$ methanol (containing $2.5 \%$ acetic acid) at a flow rate of $0.8 \mathrm{ml} / \mathrm{min}$. All 4 batches yielded congruent chromatograms, which were also comparable to that of Natural Red 24 (MP Biomedicals, USA, LOT \#: R25179), a commercially available Sappan wood extract (Supplementary Figure $1 \mathrm{~A}$ and $1 \mathrm{~B})$.

Brazilin was isolated from CSE using preparative HPLC (Shimadzu, Japan) with a reversed - phase C18 column (Polygoprep C18, 12 $\mu, 25 \mathrm{~mm} \times 250 \mathrm{~mm}$, Austria) monitored at $280 \mathrm{~nm}$. The eluent system consisted of a 45 min gradient program from $10 \%$ to $100 \%$ methanol (containing $1.25 \%$ acetic acid) at a flow rate of $22 \mathrm{ml} / \mathrm{min}$ and a column temperature of $50^{\circ} \mathrm{C}$. The fraction at a retention time of about $20 \mathrm{~min}$ was collected in repeated preparative HPLC separations. These fractions were further concentrated under reduced pressure and then freeze-dried to give a white compound which rapidly oxidized to a red-brown powder. In accordance with Chen et al. (Chen et al., 2008), the isolated compound was identified as brazilin ((6aS,11bR)-7,11b-Dihydro-6H-indeno[2,1-c]chromene-3,6a,9,10-tetrol) using ${ }^{1} \mathrm{H}$ NMR (Bruker Avance 500 instrument, Bruker, USA). The HPLC chromatogram of brazilin is shown in Supplementary Figure 1C.

\subsection{Cell cultures}

In accordance with the terms of the ethics committee of the Medical University Vienna (EKNr.: 081/2005) and following the guidelines of the Declaration of Helsinki and Tokyo, 
primary human chondrocytes were enzymatically isolated from articular cartilage of OA patients undergoing knee replacement surgery following established protocols (Toegel et al., 2009; Toegel et al., 2010). Isolated chondrocytes were seeded at a density of $10^{5} / \mathrm{cm}^{2}$ and cultured in Dulbecco's modified Eagle's medium (DMEM; Gibco, A) containing 10\% fetal calf serum (FCS; Biochrom AG, D) and $2 \mu \mathrm{l} / \mathrm{ml}$ gentamycin (Biochrom AG, D) in a humidified atmosphere of $5 \% \mathrm{CO}_{2} / 95 \%$ air at $37^{\circ} \mathrm{C}$. For all assays, only freshly isolated and seeded cells without subculturing were used. The human chondrosarcoma cell line SW1353 (ATCC, USA) was cultured at a density of $10^{4} / \mathrm{cm}^{2}$ under the same conditions as described above and passaged by incubation with $0.25 \%$ trypsin-EDTA. The human monocytic cell line THP-1 (ATCC, USA) was maintained in RPMI 1640 medium supplemented with 10\% FCS, $4 \mathrm{mM} \mathrm{L-glutamine,} \mathrm{and} 104 \mathrm{U} / \mathrm{ml}$ penicillin (Gibco, A) in a humidified atmosphere of $5 \% \mathrm{CO}_{2} / 95 \%$ air at $37^{\circ} \mathrm{C}$. Cells were differentiated into macrophages in the above medium containing $5 \mathrm{ng} / \mathrm{ml}$ phorbol 12-myristate 13-acetate (PMA) over $24 \mathrm{~h}$. After washing once, cultures were changed to medium without PMA for $24 \mathrm{~h}$ and then used for further studies.

\subsection{Cytotoxicity assay}

The cytotoxicity of CSE was assessed in primary human chondrocytes and THP-1 cells using an MTT-based test (EZ4U, Biomedica, A) following the manufacturer's instructions. Briefly, $3 \times 10^{3}$ cells/well were seeded in quadruplicate in 96-well microplates (Iwaki, J) and cultured with various concentrations of CSE $(0.625$ to $40 \mu \mathrm{g} / \mathrm{ml})$ for 3 days. The absorbance was recorded by a Spectrafluor Fluorometer (Tecan, A) at $450 \mathrm{~nm}$ with $620 \mathrm{~nm}$ as reference wave length.

\subsection{Griess assay}

Primary human OA chondrocytes ( $\mathrm{n}=3$ donors) were seeded in 96-well microplates and analyzed separately. Upon confluency, cells were preincubated with CSE at three concentrations ( $10 \mu \mathrm{g} / \mathrm{ml}, 5 \mu \mathrm{g} / \mathrm{ml}$ or $2.5 \mu \mathrm{g} / \mathrm{ml}$ ) for $1 \mathrm{~h}$ prior to coincubation with $10 \mathrm{ng} / \mathrm{ml}$ IL-1ß (Miltenyi Biotec, D) for $24 \mathrm{~h}$. The amount of accumulated nitrite derived from NO metabolism was determined in the cell culture supernatant by mixing with an equal volume of Griess reagent ( $1 \%$ sulphanilamide in $0.1 \mathrm{~N} \mathrm{HCl}$ and $0.1 \% \mathrm{~N}$-1-naphthylethylenediamine dihydrochloride in equal parts). Absorbance was measured at $544 \mathrm{~nm}$ with reference to 690 $\mathrm{nm}$ with a Spectrafluor Fluorometer. Nitrite concentrations were calculated using a $\mathrm{NaNO}_{2}$ standard curve $(0-100 \mu \mathrm{M}$ in cell culture medium). A nitrite standard reference curve was established for each assay.

\subsection{Quantitative real-time RT-PCR (RT-qPCR)}

$4 \times 10^{5} /$ well primary human OA chondrocytes or $4 \times 10^{4} /$ well SW1353 cells were seeded in 12-well microplates (Iwaki, J). Upon 90\% confluency, medium was changed to DMEM containing 2\% Insulin-Transferrin-Selenium (ITS; Gibco, A) and incubated overnight prior to treatment. Chondrocytes were preincubated with CSE $(5,10$, or $20 \mu \mathrm{g} / \mathrm{ml})$ or $10 \mu \mathrm{M}$ dexamethasone (Sigma, A) for $1 \mathrm{~h}$ and then incubated for a further $6 \mathrm{~h}$ in the presence of 10 $\mathrm{ng} / \mathrm{ml} \mathrm{IL-1ß}$. In a different set of experiment, cells were pretreated with $10 \mu \mathrm{g} / \mathrm{ml}$ Natural Red 24 (NR24). Cells without any treatment were used as control. THP-1 cells were seeded in 12-well microplates at $3 \times 10^{5}$ per well. After differentiation with PMA (see above), cells were preincubated with $5 \mu \mathrm{g} / \mathrm{ml} \mathrm{CSE}$ for $1 \mathrm{~h}$ and then co-treated for an additional $2 \mathrm{~h}$ with $10 \mathrm{ng} / \mathrm{ml}$ LPS.

Total RNA was extracted from each sample using the NucleoSpin RNA II Kit (MachereyNagel, D) according to the manufacturer's instructions. To quantify and control for the integrity of the isolated RNA preparations, each sample was run on the Agilent 2100 Bioanalyzer Nano LabChip prior to reverse transcription of equal RNA quantities into 
cDNA using the High Capacity cDNA Reverse Transcription Kit (Applied Biosystems, A). RNA integrity numbers (RIN) were found to range from 7.8 to 10 for all samples.

qPCR analyses of IL- $1 \beta$, TNF- $\alpha$, iNOS and COX- 2 mRNA were performed using primer sets described in Table 1. Primers for reference genes were used as previously described (Toegel et al., 2007). Amplification efficiencies of all primers were evaluated using dilution series of cDNA prepared from chondrocyte mRNA. All qPCR reactions were performed in $25 \mu \mathrm{l}$ reaction mixtures containing $1 \mu \mathrm{l}$ cDNA, $12.5 \mu \mathrm{l}$ SensiMix SYBR Green Mix (GenXpress, A), $100 \mathrm{nM}$ primers (Metabion, D), and nuclease-free water to $25 \mu \mathrm{l}$, and run in duplicate on an Mx3000P QPCR system (Stratagene, USA). Melting curves were generated to confirm a single gene-specific peak and no-template-controls were included in each run to control for contaminations.

The regulation of target genes was calculated as quantities relative to the untreated control group using the MxPro real-time QPCR software, considering both amplification efficiencies and normalization to glyceraldehyde-3-phosphate dehydrogenase (GAPDH) as reference gene. In preliminary experiments, the expression stabilities of 5 candidate reference genes (GAPDH, beta actin (ACTB), hypoxanthine phosphoribosyl-transferase I (HPRT1), succinate dehydrogenase complex, subunit A (SDHA), beta-2-microglobulin (B2M)) were determined under the experimental conditions described above. Then, the expression stabilities were evaluated using the geNorm software (Vandesomp et al., 2002) and GAPDH was selected as a stable reference gene under the experimental conditions of this study.

We declare that the current study has adhered to the minimal guidelines for the design and documentation of qPCR experiments as recently outlined by Bustin et al (Bustin et al., 2010). A qPCR checklist listing all relevant technical information has been provided for the reviewers to assess the technical adequacy of the used qPCR protocols (Supplementary Table 1).

\subsection{TNF- $\alpha$ ELISA}

$4 \times 10^{5} /$ well primary human OA chondrocytes from donors ( $\mathrm{n}=2$ donors) or $4 \times 10^{4} /$ well SW1353 cells were seeded in 12-well microplates. Upon 90\% confluency, culture medium was changed to DMEM containing $2 \%$ ITS and cultured overnight. After $1 \mathrm{~h}$ preincubation with $5 \mu \mathrm{g} / \mathrm{ml} \mathrm{CSE}$, the cells were treated with $10 \mathrm{ng} / \mathrm{ml} \mathrm{IL-} 1 \beta$ for an additional $48 \mathrm{~h}$. Chondrocytes without any treatment were used as control. The TNF- $\alpha$ concentration in the cell culture supernatants was measured using the Human TNF alpha ELISA Ready-SET-Go! Kit (eBioscience, USA), as described by the manufacturer.

\subsection{Transfections and reporter assays}

The pXP2-COX2-Luc reporter construct, containing -170/+103 bp of the human COX2 promoter, and the NF-kB p50 and p65 expression vectors were described previously (Grall et al., 2005). The sequences of all constructs were confirmed by DNA sequencing.

Transient transfection experiments were performed in SW1353 cells using LipofectAMINE PLUS Reagent (Invitrogen, A). Cells were seeded in 24-well plates at $10^{4} \mathrm{cells} / \mathrm{cm}^{2}$ in DMEM/F12 containing 10\% FCS. Transfections were carried out in serum-free medium with a total of no more than $325 \mathrm{ng}$ of plasmid DNA, including $300 \mathrm{ng}$ of luciferase reporter construct and $25 \mathrm{ng}$ per well of expression vector or empty backbone (control). Briefly, plasmid DNA was incubated for 15 min at room temperature with $6 \mu \mathrm{l}$ Plus Reagent and 94 $\mu \mathrm{l}$ serum-free DMEM/F12. Following incubation, LipofectAMINE reagent (4 $\mu \mathrm{l})$ in $96 \mu \mathrm{l}$ serum-free medium was added to each reaction mixture and the incubation was continued for an additional $30 \mathrm{~min}$ at room temperature. Then, the transfection mixture was combined 
with $300 \mu \mathrm{l}$ of serum-free medium and the lipid-nucleic acid complex $(500 \mu \mathrm{l})$ was added drop-wise to the cell monolayer yielding a total volume of $1 \mathrm{ml}$. After incubation for $1 \mathrm{~h}$ at $37^{\circ} \mathrm{C}, 1 \mathrm{ml}$ of serum-free medium containing CSE was added to each well and incubation was continued for $23 \mathrm{~h}$. Cell lysates were prepared using the Reporter Lysis Buffer (Promega, USA) and luciferase activities were determined by chemiluminescence assay using the LMaxII384 luminometer (Molecular Devices, USA) and the Luciferase Assay Substrate (Promega). Data are representative of two independent experiments performed in triplicate and expressed as fold-change versus unstimulated control.

\subsection{Statistical Analysis}

Data were exported to the GraphPad Prism statistics software package (GraphPad Prism Software, USA). The Gaussian distribution of data was verified using the KolmogorovSmirnov test. Statistics were performed using one-way analysis of variance (ANOVA) with post hoc Tukey tests, cross-comparing all study groups (95\% confidence interval). p-values $<0.05$ were considered significant.

\section{Results}

\subsection{Effect of CSE on cell viability}

As shown in Figure 1, significant cytotoxicity of CSE was observed at concentrations higher than $40 \mu \mathrm{g} / \mathrm{ml}$ and $10 \mu \mathrm{g} / \mathrm{ml}$ in primary chondrocytes and THP- 1 cells, respectively. The subsequent experiments were therefore performed using CSE concentrations not higher than $20 \mu \mathrm{g} / \mathrm{ml}$ for experiments carried out using human primary chondrocytes and at $5 \mu \mathrm{g} / \mathrm{ml}$ for treatment of THP-1 cells.

\subsection{Effect of CSE on IL-1ß and TNF- $\alpha$ mRNA in THP-1 cells}

In THP-1 macrophages, $10 \mathrm{ng} / \mathrm{ml}$ LPS induced an $11.9 \pm 0.6$ fold and $60.2 \pm 7.2$ fold upregulation of IL-1 $\beta$ (Figure 2A) and TNF- $\alpha$ (Figure 2B) mRNA levels, respectively. Pretreatment with $5 \mu \mathrm{g} / \mathrm{ml} \mathrm{CSE} \mathrm{significantly} \mathrm{inhibited} \mathrm{the} \mathrm{upregulation} \mathrm{of} \mathrm{both} \mathrm{cytokines} \mathrm{in}$ THP-1 macrophages. In the case of TNF- $\alpha$, CSE pretreatment down-regulated the mRNA expression to levels comparable to control cells (Figure 2B).

\subsection{Effect of CSE on IL-1ß and TNF- $\alpha$ expression in chondrocytes}

As shown in Figure 3A, IL-1ß gene expression in SW1353 chondrocytes was upregulated by $45.3 \pm 2.5$ fold following stimulation with $10 \mathrm{ng} / \mathrm{ml}$ recombinant IL-1B. CSE, however, markedly suppressed the effect caused by IL- $1 \beta$ in a concentration-dependent manner. At 10 and $20 \mu \mathrm{g} / \mathrm{ml}$, CSE completely blocked the IL-1ß-induced IL-1ß mRNA level, reestablishing expression levels comparable to untreated cells. The TNF- $\alpha$ mRNA level

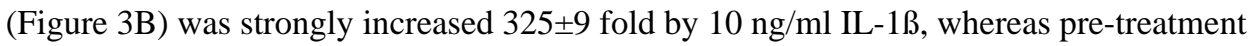
with 10 or $20 \mu \mathrm{g} / \mathrm{ml}$ CSE significantly reduced this effect. In addition, comparable results regarding the impact of CSE on IL- $1 \beta$ and TNF- $\alpha$ mRNA expression were obtained in primary chondrocytes (Table 2 ). Interestingly, the upregulation of IL- $1 \beta$ and TNF- $\alpha$ mRNA expression caused by IL-1ß was considerable higher in primary chondrocytes than in SW1353 cells. Nevertheless, the stimulated expression of IL-1ß and TNF- $\alpha$ mRNA was clearly abrogated by CSE treatment in a dose-dependent manner. The validity of the assay was verified using $10 \mu \mathrm{M}$ dexamethasone, a widely used anti-inflammatory glucocorticoid, as positive control. Dexamethasone substantially suppressed the IL-1ß-mediated upregulation of IL- $1 \beta$ and TNF- $\alpha$ mRNA levels in primary chondrocytes isolated from 3 donors $(\mathrm{p}<0.05$; data not shown).

Interestingly, also NR24 down-regulated TNF- $\alpha$ mRNA levels in IL-1ß stimulated primary chondrocytes (Supplementary Figure 2). Even more importantly, the inhibitory effects 
mediated by NR24 were significantly less pronounced than those mediated by CSE $(\mathrm{p}<0.05)$. This fact might be explained by the lower concentration of brazilin found in NR24 as compared to CSE (Supplementary Figure 1).

The production of TNF- $\alpha$ was measured in the culture supernatants of chondrocytes using ELISA. As shown in Figure 4, $24 \mathrm{~h}$ treatment with IL-1ß $(10 \mathrm{ng} / \mathrm{ml})$ caused a 3.6 fold and 9.1 fold increase of TNF- $\alpha$ expression in SW1353 chondrocytes and primary human chondrocytes, respectively. Pretreatment of both cell types with $5 \mu \mathrm{g} / \mathrm{ml} \mathrm{CSE} \mathrm{significantly}$ suppressed the IL-1ß-induced TNF- $\alpha$ production. As such, $5 \mu \mathrm{g} / \mathrm{ml} \mathrm{CSE}$ reduced the IL- $1 \beta$ induced TNF- $\alpha$ production in primary cells from $19.1 \pm 1.1 \mathrm{pg} / \mathrm{ml}$ to $5.4 \pm 3.8 \mathrm{pg} / \mathrm{ml}$. In both SW1353 and primary cells, the TNF- $\alpha$ production was down-regulated to basal levels.

\subsection{Effect of CSE on NO production and on iNOS expression}

Nitrite, the stable metabolite of NO, was measured using the Griess assay in primary chondrocytes. Stimulation with IL- $1 \beta$ resulted in a $16.3 \pm 4.9$ fold increase of nitrite accumulation whereas pretreatment with CSE caused a concentration-dependent reduction of nitrite accumulation (Figure 5). $5 \mu \mathrm{g} / \mathrm{ml}$ and $10 \mu \mathrm{g} / \mathrm{ml}$ CSE significantly suppressed the IL-1ß-induced NO production to basal levels. At $2.5 \mu \mathrm{g} / \mathrm{ml}$, CSE did not exert a statistically significant effect in this assay. For correlation, RT-qPCR was performed to quantify iNOS mRNA levels in IL-1ß-stimulated SW1353 and primary chondrocytes as well as in LPSstimulated THP-1 cells. As shown in Figure 3C and Table 2, $10 \mathrm{ng} / \mathrm{ml} \mathrm{IL-1ß} \mathrm{markedly}$ stimulated iNOS expression in SW1353 cells and primary chondrocytes, respectively. Pretreatment with CSE dose-dependently suppressed iNOS expression to control levels, supporting the results obtained with the Griess assay. A similar, albeit not significant, trend was also observed in THP-1 cells (Figure 2C).

\subsection{Effect of CSE on COX-2 transcription via p65/p50-mediated COX-2 promoter activation}

As shown in Figure 3D, IL-1 $\beta$-induced COX-2 expression was significantly reduced by CSE pretreatment in SW1353 chondrocytes. Accordingly, IL-1ß-induced COX-2 mRNA levels were reduced in a dose-dependent manner by CSE in human primary chondrocytes (Table 2). Previous studies have shown that IL- $1 \beta$ activates COX-2 expression via NF- $\kappa B$ signaling in different cell types, including chondrocytes (Allport et al., 2000; Thomas et al., 2000; Croffort et al., 1997). Therefore, in order to elucidate the mechanism underlying COX-2 suppression by CSE, SW1353 cells were co-transfected with a COX-2 reporter construct and $\mathrm{NF}-\kappa \mathrm{B}$ p65/p50 expression vectors in the presence or absence of CSE. As shown in Figure 6 , the basal COX-2 promoter activity was reduced by 2.5 and $5 \mu \mathrm{g} / \mathrm{ml} \mathrm{CSE}$, although the differences were not statistically significant. Overexpression of the NF- $\mathrm{BB}$ subunits $\mathrm{p} 50$ and p65 significantly enhanced the COX-2 promoter activity $(3.4 \pm 0.7$ fold, $\mathrm{p}<0.05)$ whereas the p65/p50-driven COX-2 transactivation was dose-dependently suppressed by CSE (0.5-10 $\mu \mathrm{g} / \mathrm{ml}$ ), indicating that the anti-inflammatory effects of CSE are, at least in part, derived from its actions on NF- $\mathrm{KB}$ signaling.

\section{Discussion}

It is now accepted that inflammatory processes play a role in the pathophysiology of OA. Indeed, different studies have shown that joint tissue cells, including synovial fibroblasts, synovial macrophages and chondrocytes, produce proinflammatory cytokines, chemokines and other proinflammatory mediators that will in turn result in an inflammatory environment that drives the upregulation of cartilage-degrading MMPs and ADAMTSs (Bodenson et al., 2006; Tsuruda et al., 2004). 
Using human OA chondrocytes and THP-1 macrophages, the present study demonstrates for the first time that CSE is a potent inhibitor of proinflammatory mediators in the context of joint inflammation. Several lines of evidence have previously demonstrated the antiinflammatory potential of Caesalpinia sappan extracts and their isolated compounds. In LPS-stimulated RAW264.7 mouse macrophages, Hu and coworkers found that brazilin, the main constituent of CSE, suppressed the release of IL-1ß, TNF- $\alpha$, NO, and $\mathrm{PGE}_{2}$ and they suggested that these effects are mediated by Heme oxygenase-1 (Hu et al., 2009).

Washiyama et al. compared seven compounds isolated from a methanolic extract of Sappan lignum in mouse macrophage-like J774.1 cells and demonstrated inhibitory effects on the expression of inflammatory mediators (Washiyama et al., 2009). More importantly, in vivo data from mouse and rat models further support our findings on the anti-inflammatory activity of Caesalpinia sappan isolates (Washiyama et al., 2009; Shen et al., 2007). Only recently, a 70\% ethanolic extract of Caesalpinia sappan has been evaluated in a human cell model of TNF- $\alpha$-stimulated umbilical vein endothelial cells (Lee et al., 2010). Our present study extends these results to human macrophages and shows that CSE down-regulates IL- $1 \beta$ and TNF- $\alpha$ mRNA levels in activated THP- 1 cells. This result is of interest since synovial macrophages are known to contribute to the pathogenic cascade that leads to OA and rheumatoid arthritis as a major source of inflammatory cytokines and reactive oxygen intermediates (Bondeson et al., 2006). Targeting macrophages using anti-inflammatory phytopharmaceuticals may, therefore, represent a strategy to alleviate synovitis and deleterious mediators in the synovial fluid.

Besides synovial macrophages, OA chondrocytes are a promising target of antiinflammatory agents. Our present results clearly document that the addition of CSE effectively suppresses the over-expression of IL- $1 \beta$ and TNF- $\alpha$ in stimulated OA chondrocytes as well as SW1353 cells in vitro, indicating that CSE contains one or more active components that may act as potent anti-inflammatory agents in human chondrocytes. Most likely, brazilin ((6aS,11bR)-7,11b-Dihydro-6H-indeno[2,1-c]chromene-3,6a,9,10tetrol) contributes to the described anti-inflammatory action of CSE. In the present study, we have isolated brazilin from CSE and identified its structure using ${ }^{1} \mathrm{H}$ NMR. Interestingly, we found that CSE suppressed the IL-1ß-mediated upregulation of TNF- $\alpha$ mRNA levels to a significantly higher extent than NR24. This finding correlates with the lower content of brazilin in NR24 as demonstrated using HPLC analysis and supports the role of brazilin in the anti-inflammatory action of CSE in human chondrocytes.

One of the biological messengers associated with inflammation is NO. NO is biosynthesized endogenously from L-arginine by nitric oxide synthases and can activate transcription factors or protein kinases in a cGMP-dependent manner. Although NO might also regulate physiological processes in chondrocytes, including collagen type $\mathrm{X}$ expression and alkaline phosphatase activity, several reports have shown that OA chondrocytes overexpress iNOS and that the resulting excess NO production by OA chondrocytes is a contributing factor to OA cartilage degradative processes (Abramson, 2008; Studer et al., 1999). Experiments in other cell types have indicated that the anti-inflammatory activity of CSE involves the reduction of NO synthesis via inhibition of iNOS mRNA expression (Washiyama et al., 2009; Bae et al., 2005). The latter led us to explore the action of CSE in human OA chondrocytes where, in agreement with the aforementioned reports, we demonstrated that the presence of the extract abrogates IL-1ß-mediated NO production by suppressing iNOS transcription. This suggests that CSE might alleviate deleterious effects associated with over-expression of NO such as the inhibition of collagen and proteoglycan synthesis and the induction of apoptosis (Abramson, 2008).

Furthermore, inflammatory cytokines increase the production of prostaglandins via the induction of COX-2 and microsomal PGE synthase 1 (Abramson and Attur, 2009). Attur 
and coworkers reported that $\mathrm{PGE}_{2}$ decreased proteoglycan synthesis and enhanced matrix degradation in OA cartilage explants (Attur et al., 2008). RT-qPCR results reported in the present study indicate that CSE is able to attenuate IL-1ß-induced COX-2 mRNA expression in SW1353 and primary chondrocytes. This result correlates well with studies on CSE and brazilin in mouse macrophages, demonstrating that the potential anti-inflammatory effects of the agents involve the inhibition of $\mathrm{PGE}_{2}$ production (Hong et al., 2002; Sasaki et al., 2007). Aiming to further elucidate the mechanisms underlying the anti-inflammatory action of CSE in chondrocytes, we focused on the role of NF- $\mathrm{KB}$ in COX-2 promoter activation. The NF$\kappa \mathrm{B}$ signaling is activated by pro-inflammatory stimuli including IL- $1 ß$ and TNF- $\alpha$. Activated NF- $\kappa B$ subunits, such as the RelA (p65)/p50 heterodimer, are translocated to the nucleus, where they bind to target DNA sequences and regulate the expression of a number of genes, including COX-2, iNOS, IL- $1 \beta$ and TNF- $\alpha$. The COX-2 promoter contains at least four

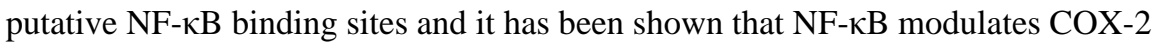
expression in different cell types, including epithelial cells, rheumatoid synoviocytes and articular chondrocytes (Allport et al., 2000; Thomas et al., 2000; Croffort et al., 1997). In the present study, co-transfection experiments utilizing a COX-2 promoter luciferase construct and p65/p50 expression vectors in the presence or absence of CSE, revealed that CSE strongly inhibited the p65/p50-driven COX-2 transactivation in a dose-dependent manner. This result suggests that CSE interferes with the DNA binding activity of NF- $\kappa B$ subunits, thereby blocking COX-2 transcription. This finding is in agreement with a previous study by Bae et al. showing that brazilin inhibited the DNA binding activity of NF- $\mathrm{KB}$ and AP-1 in LPS-stimulated mouse macrophages (Bae et al., 2005).

Finally, it should be noted that the present study is limited in terms of its in vitro experimental design and that extrapolations to in vivo conditions should be carried out with caution. Future studies should aim to define the in vivo actions of CSE using animal models of arthritic diseases, and to further delineate the molecular mechanisms evoked by CSE and its specific constituents. As any other phytochemical drug, CSE or CSE-derived compounds will also require rigorous toxicological and pharmacokinetic testing as well as clinical verification of the findings obtained in vitro.

\section{Conclusion}

In this study, we demonstrated that CSE possesses anti-inflammatory activity in human macrophages and OA chondrocytes. In these cells, CSE substantially suppresses the expression of inflammatory mediators including IL- $1 \beta$ and TNF- $\alpha$ at the mRNA level. In addition, we show that the anti-inflammatory actions of CSE involve, at least in part, the inhibition of NO production via iNOS downregulation as well as the inhibition of COX-2 promoter activation by interfering with the canonical NF- $\mathrm{KB}$ (p65/p50) signaling pathway. Therefore, we suggest that CSE or CSE-derived compounds should be further developed as therapeutically effective agents or lead structures for future treatment of inflammation in OA.

\section{Supplementary Material}

Refer to Web version on PubMed Central for supplementary material.

\section{Acknowledgments}

The authors wish to thank Diana Berner for technical assistance. Gottfried Reznicek and Wolfgang Holzer are acknowledged for support and advice. This research was supported partially by the Stratagene Research Grant (ST), the NIH grant R01-AG022021 (MBG), an Arthritis Foundation Postdoctoral Fellowship (MO), and the graduate program 'Molecular Drug Targets' sponsored by the University of Vienna (SQW). 


\section{References}

Abramson SB. Nitric oxide in inflammation and pain associated with osteoarthritis. Arthritis Research \& Therapy. 2008; (Suppl. 2):2.

Abramson SB, Attur M. Developments in the scientific understanding of osteoarthritis. Arthritis Research \& Therapy. 2009; 11:227. [PubMed: 19519925]

Allport VC, Slater DM, Newton R, Bennett PR. NF-kappaB and AP-1 are required for cyclooxygenase 2 gene expression in amnion epithelial cell line (WISH). Molecular Human Reproduction. 2000; 6:561-565. [PubMed: 10825375]

Ameye LG, Chee WS. Osteoarthritis and nutrition. From nutraceuticals to functional foods: a systematic review of the scientific evidence. Arthritis Research \& Therapy. 2009; 8:R127. [PubMed: 16859534]

Attur M, Al-Mussawir HE, Patel J, Kitay A, Dave M, Palmer G, Pillinger MH, Abramson SB. Prostaglandin E2 exerts catabolic effects in osteoarthritis cartilage: evidence for signaling via the EP4 receptor. Journal of Immunology. 2008; 181:5082-5088.

Badami S, Moorkoth S, Rai SR, Kannan E, Bhojraj S. Antioxidant activity of Caesalpinia sappan heartwood. Biological and Pharmaceutical Bulletin. 2003; 26:1534-1537. [PubMed: 14600396]

Bae IK, Min HY, Han AR, Seo EK, Lee SK. Suppression of lipopolysaccharide-induced expression of inducible nitric oxide synthase by brazilin in RAW 264.7 macrophage cells. European Journal of Pharmacology. 2005; 513:237-242. [PubMed: 15862806]

Baek NI, Jeon SG, Ahn EM, Hahn JT, Bahn JH, Jang JS, Cho SW, Park JK, Choi SY. Anticonvulsant compounds from the wood of Caesalpinia sappan L. Archives of Pharmacal Research. 2000; 23:344-348. [PubMed: 10976581]

Batubara I, Mitsunaga T, Ohashi H. Brazilin from Caesalpinia sappan wood as an antiacne agent. Journal of wood science. 2010; 56:77-81.

Benito MJ, Veale DJ, FitzGerald O, van den Berg WB, Bresnihan B. Synovial tissue inflammation in early and late osteoarthritis. Annals of the Rheumatic Diseases. 2005; 64:1263-1267. [PubMed: 15731292]

Bondeson J, Wainwright SD, Lauder S, Amos N, Hughes CE. The role of synovial macrophages and macrophage-produced cytokines in driving aggrecanases, matrix metalloproteinases, and other destructive and inflammatory responses in osteoarthritis. Arthritis Research \& Therapy. 2006; $8: 187$.

Bonnet CS, Walsh DA. Osteoarthritis, angiogenesis and inflammation. Rheumatology. 2005; 44:7-16. [PubMed: 15292527]

Bustin SA, Beaulieu JF, Huggett J, Jaggi R, Kibenge FS, Olsvik PA, Penning LC, Toegel S. MIQE précis: Practical implementation of minimum standard guidelines for fluorescence-based quantitative real-time PCR experiments. BMC Molecular Biology. 2010; 11:74. [PubMed: 20858237]

Chen YP, Liu L, Zhou YH, Wen J, Jiang Y, Tu PF. Chemical constituents from Sappan Lignum. Journal of Chinese Pharmaceutical Sciences. 2008; 17:82-86.

China Pharmacopoeia Commission. The Chinese Pharmacopoeia. 2010. China Medical Science Press; Beijing: 2010. p. 153

Clutterbuck AL, Asplin KE, Harris P, Allaway D, Mobasheri A. Targeting matrix metalloproteinases in inflammatory conditions. Current Drug Target. 2009; 10:1245-1254.

Crofford LJ, Tan B, McCarthy CJ, Hla T. Involvement of nuclear factor kappa B in the regulation of cyclooxygenase-2 expression by interleukin-1 in rheumatoid synoviocytes. Arthritis \& Rheumatism. 1997; 40:226-236. [PubMed: 9041934]

Fendrick AM, Greenberg BP. A review of the benefits and risks of nonsteroidal anti-inflammatory drugs in the management of mild-to-moderate osteoarthritis. Osteopathic Medicine and Primary Care. 2009; 3:1.

Goldring MB, Goldring SR. Osteoarthritis. Journal of Cellular Physiology. 2007; 213:626-634. [PubMed: 17786965]

Goldring MB, Marcu KB. Cartilage homeostasis in health and rheumatic diseases. Arthritis Research \& Therapy. 2009; 11:224. [PubMed: 19519926] 
Gosset M, Pigenet A, Salvat C, Berenbaum F, Jacques C. Inhibition of Matrix Metalloproteinase-3 and -13 Synthesis Induced by IL-1 $\{$ beta\} in Chondrocytes from Mice Lacking Microsomal Prostaglandin E Synthase-1. Journal of Immunology. 2010 in press.

Grall FT, Prall WC, Wei W, Gu X, Cho JY, Choy BK, Zerbini LF, Inan MS, Goldring SR, Gravallese EM, Goldring MB, Oettgen P, Libermann TA. The Ets transcription factor ESE-1 mediates induction of the COX-2 gene by LPS in monocytes. The FEBS Journal. 2005; 272:1676-1687. [PubMed: 15794755]

Hong CH, Hur SK, Oh OJ, Kim SS, Nam KA, Lee SK. Evaluation of natural products on inhibition of inducible cyclooxygenase (COX-2) and nitric oxide synthase (iNOS) in cultured mouse macrophage cells. Journal of Ethnopharmacology. 2002; 83:153-159. [PubMed: 12413723]

Hikino H, Taguchi T, Fujimura H, Hiramatsu Y. Antiinflammatory principles of Caesalpinia sappan wood and of Haematoxylon campechianum wood. Planta Medica. 1977; 31:214-220. [PubMed: 866477]

Hu CM, Liu YH, Cheah KP, Li JS, Lam CS, Yu WY, Choy CS. Heme oxygenase-1 mediates the inhibitory actions of brazilin in RAW264.7 macrophages stimulated with lipopolysaccharide. Journal of Ethnopharmacology. 2009; 121:79-85. [PubMed: 18983903]

Jeong IY, Jin CH, Park YD, Lee HJ, Choi DS, Byun MW, Kim YJ. Anti-inflammatory Activity of an Ethanol Extract of Caesalpinia sappan L. in LPS-induced RAW 264.7 Cells. Journal of Food Science and Nutrition. 2008; 13:253-258.

Lee MJ, Lee HS, Jung HJ, Lee CS, Kim JE, Moon HI, Park WH. Caesalpinia sappan L. ameliorates hypercholesterolemia in C57BL/6 mice and suppresses inflammatory responses in human umbilical vein endothelial cells (HUVECs) by antioxidant mechanism. Immunopharmacology and Immunotoxicology. 2010; 32:671-679. [PubMed: 20230182]

Liu AL, Shu SH, Qin HL, Lee SM, Wang YT, Du GH. In vitro anti-influenza viral activities of constituents from Caesalpinia sappan. Planta medica. 2009; 75:337-339. [PubMed: 19148862]

Sasaki Y, Hosokawa T, Nagai M, Nagumo S. In vitro study for inhibition of NO production about constituents of Sappan Lignum. Biological \& Pharmaceutical Bulletin. 2007; 30:193-196. [PubMed: 17202686]

Shen J, Zhang H, Lin H, Su H, Xing D, Du L. Brazilein protects the brain against focal cerebral ischemia reperfusion injury correlating to inflammatory response suppression. European Journal of Pharmacology. 2007; 558:88-95. [PubMed: 17239368]

Sireeratawong S, Piyabhan P, Singhalak T, Wongkrajang Y, Temsiririkkul R, Punsrirat J, Ruangwises N, Saraya S, Lerdvuthisopon N, Jaijoy K. Toxicity evaluation of sappan wood extract in rats. Journal of The Medical Association of Thailand. 2010; 93(suppl.7):S50-S57. [PubMed: 21294398]

Studer R, Jaffurs D, Stefanovic-Racic M, Robbins PD, Evans CH. Nitric oxide in osteoarthritis. Osteoarthritis Cartilage. 1999; 7:377-379. [PubMed: 10419772]

The Society of Japanese Pharmacopoeia. The Japanese Pharmacopoeia. 15. Hirokawa Publishing Co., Ltd; Tokyo: 2006.

Thomas B, Berenbaum F, Humbert L, Bian H, Bereziat G, Crofford L, Olivier JL. Critical role of C EBPdelta and C EBPbeta factors in the stimulation of the cyclooxygenase-2 gene transcription by interleukin-1beta in articular chondrocytes. European Journal of Biochemistry. 2000; 267:67986809. [PubMed: 11082190]

Toegel S, Huang W, Piana C, Unger FM, Wirth M, Goldring MB, Gabor F, Viernstein H. Selection of reliable reference genes for qPCR studies on chondroprotective action. BMC molecular biology. 2007; 26:8-13.

Toegel S, Plattner VE, Wu SQ, Chiari C, Gabor F, Unger FM, Goldring MB, Nehrer S, Viernstein H, Wirth M. Lectin binding patterns reflect the phenotypic status of in vitro chondrocyte models. In Vitro Cellular \& Developmental Biology - Animal. 2009; 45:351-360. [PubMed: 19263178]

Toegel S, Pabst M, Wu SQ, Grass J, Goldring MB, Chiari C, Kolb A, Altmann F, Viernstein H, Unger FM. Phenotype-related differential $\alpha$-2,6- or $\alpha$-2,3-sialylation of glycoprotein N-glycans in human chondrocytes. Osteoarthritis and Cartilage. 2010; 18:240-248. [PubMed: 19800998]

Tsuruda T, Costello-Boerrigter LC, Burnett JC. Matrix metalloproteinases: pathways of induction by bioactive molecules. Heart Failure Reviews. 2004; 9:53-61. [PubMed: 14739768] 
Vandesompele J, De Preter K, Pattyn F, Poppe B, Van Roy N, De Paepe A, Speleman F. Accurate normalization of real-time quantitative RT-PCR data by geometric averaging of multiple internal control genes. Genome Biology. 2002; 3 research0034.

Washiyama M, Sasaki Y, Hosokawa T, Nagumo S. Anti-inflammatory constituents of Sappan Lignum. Biological and Pharmaceutical Bulletin. 2009; 32:941-944. [PubMed: 19420769]

Xu HX, Lee SF. The antibacterial principle of Caesalpina sappan. Phytotherapy Research. 2004; 18:647-651. [PubMed: 15476302]

You EJ, Khil LY, Kwak WJ, Won HS, Chae SH, Lee BH, Moon CK. Effects of brazilin on the production of fructose-2,6-bisphosphate in rat hepatocytes. Journal of Ethnopharmacology. 2005; 102:53-57. [PubMed: 15994045]

\section{Glossary}

OA

CSE

IL-1B

LPS

NO

TNF- $\alpha$

iNOS

COX-2

NF-кB

ECM

MMPs

ADAMTS

$\mathrm{PGE}_{2}$

NSAIDs

DMEM

FCS

PMA

RT-qPCR

ITS

RIN

GAPDH

ACTB

HPRT1

SDHA

B2M

PC
Osteoarthritis

Ethanolic Caesalpinia sappan extract

Interleukin-1 beta

Lipopolysaccharide

Nitric oxide

Tumor necrosis factor- alpha

Inducible nitric oxide synthase

Cyclooxygenase-2

Nuclear factor-kappa-B

Extracellular matrix

Matrix metalloproteinases

A disintegrin and metalloproteinase with thrombospondin motifs

Prostaglandin $\mathrm{E}_{2}$

Nonsteroidal anti-inflammatory drugs

Dulbecco's modified Eagle's medium

Fetal calf serum

Phorbol 12-myristate 13-acetate

Quantitative real-time RT-PCR

Insulin-Transferrin-Selenium

RNA integrity numbers

Glyceraldehyde-3-phosphate dehydrogenase

Beta actin

Hypoxanthine phosphoribosyl-transferase I

Succinate dehydrogenase complex, subunit A

Beta-2-microglobulin

Primary chondrocytes 


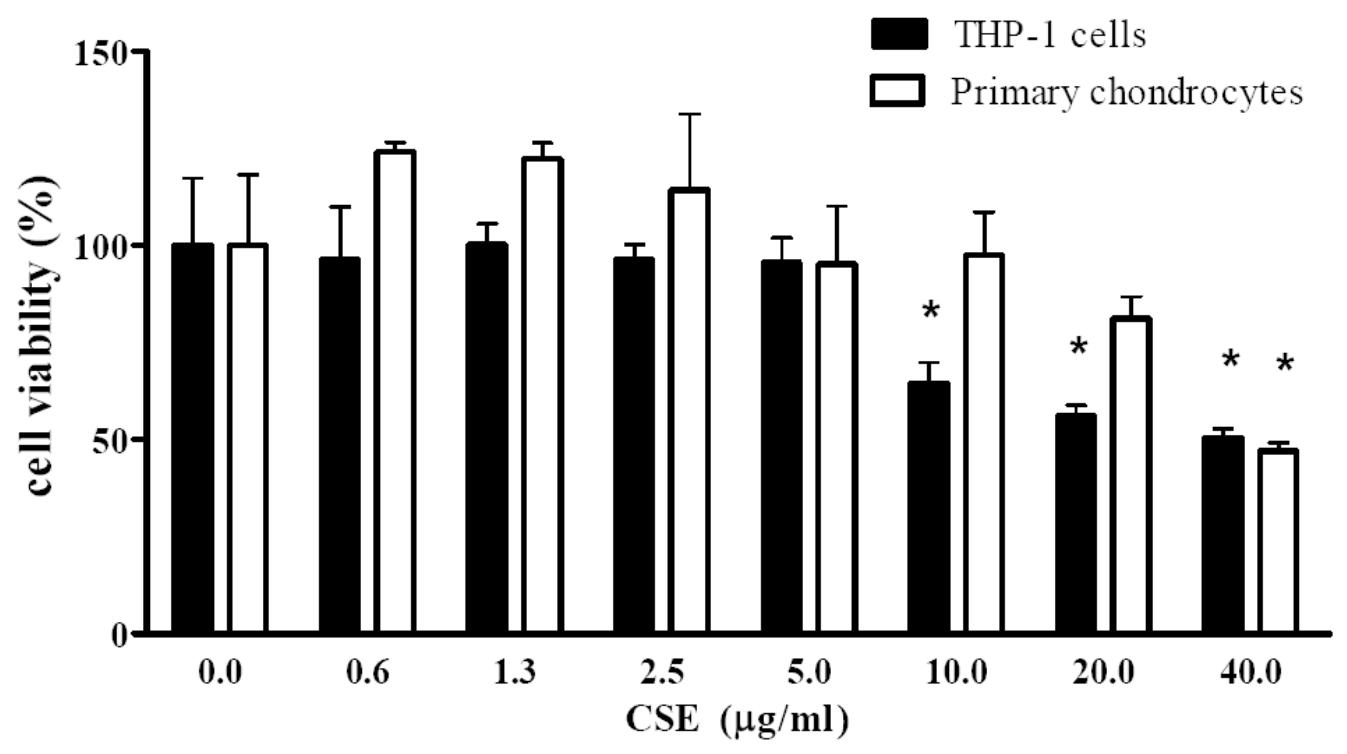

Figure 1. Cytotoxic effect of CSE in differentiated THP-1 cells and primary chondrocytes Cells were incubated for $72 \mathrm{~h}$ with various concentrations of CSE $(0.625-40 \mu \mathrm{g} / \mathrm{ml})$ and the viability was determined using MTT-based assays. Each value represents the mean \pm SD. * indicates significant differences as compared to untreated cells $(\mathrm{p}<0.05)$. 

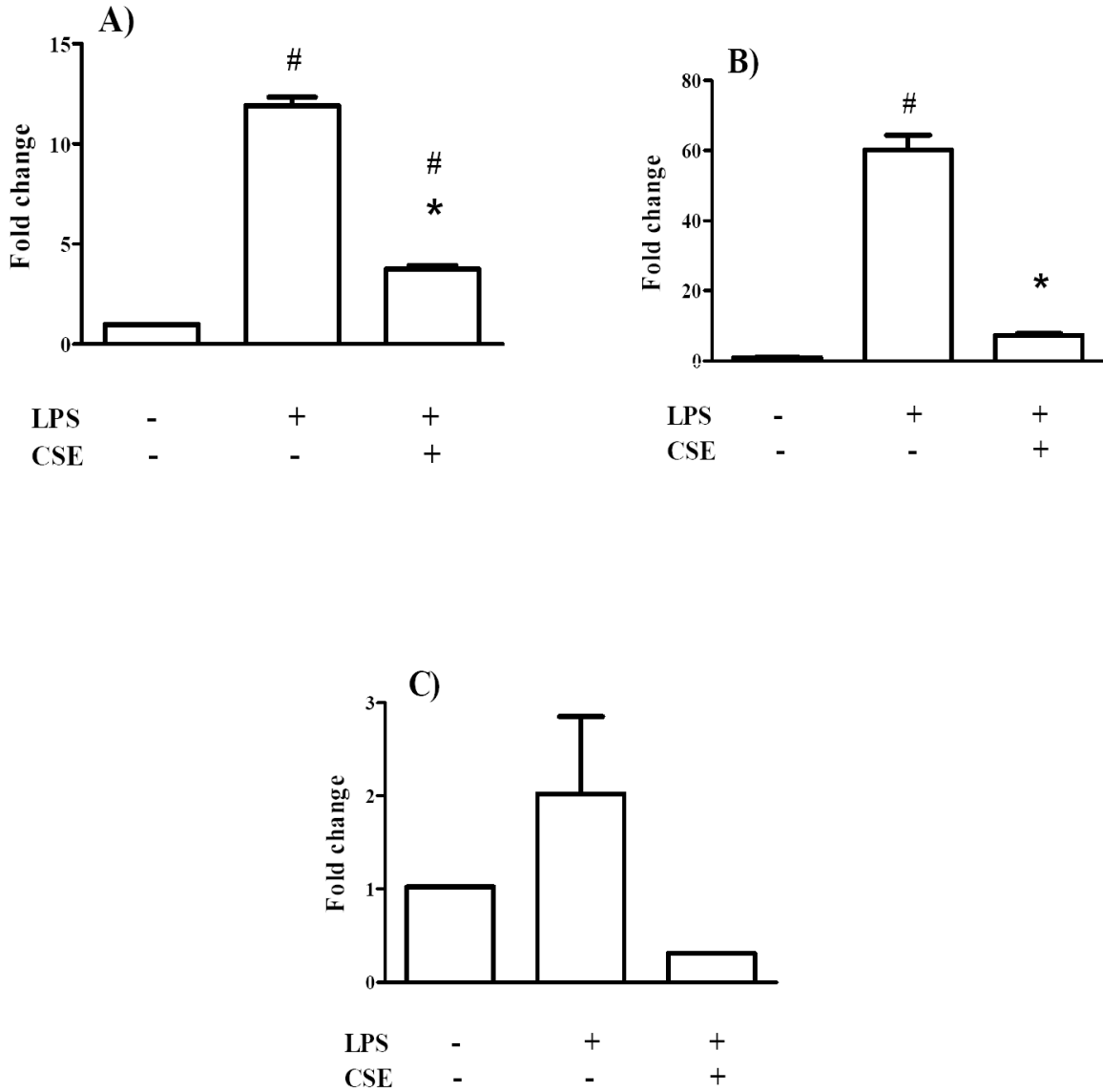

Figure 2. CSE regulates IL-1B (A), TNF- $\alpha$ (B) and iNOS (C) mRNA in THP-1 cells THP-1 cells were differentiated to macrophages using PMA and then incubated with $10 \mathrm{ng} /$ $\mathrm{ml}$ IL-1ß alone or following pretreatment with $5 \mu \mathrm{g} / \mathrm{ml} \mathrm{CSE}$. The alterations of mRNA levels were analyzed using RT-qPCR. Results are expressed as fold changes (mean \pm SD) versus controls. * indicates significant differences compared to cells treated only with IL-1ß $(p<0.05)$. \# indicates significant differences compared to untreated cells $(p<0.05)$. 

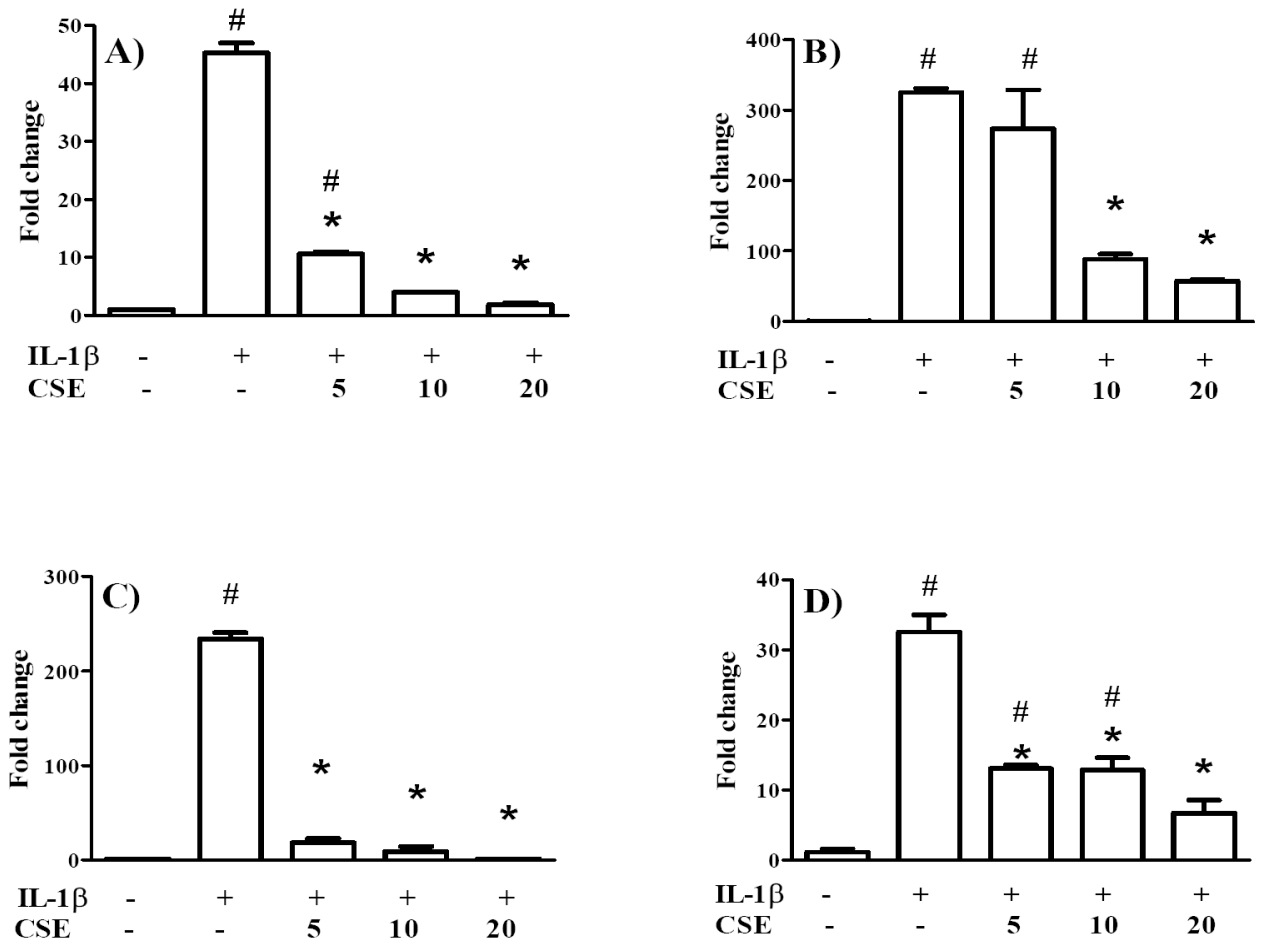

Figure 3. CSE regulates IL-1B (A), TNF- $\alpha$ (B) iNOS (C) and COX-2 (D) mRNA in SW1353 chondrocytes

Cells were preincubated with 5,10 or $20 \mu \mathrm{g} / \mathrm{ml} \mathrm{CSE}$ for $1 \mathrm{~h}$ prior to stimulation with $10 \mathrm{ng} /$ $\mathrm{ml} \mathrm{IL}-1 \beta$ for $6 \mathrm{~h}$. The alteration of mRNA levels was analyzed using RT-qPCR. Results are expressed as relative quantities (mean $\pm \mathrm{SD}$ ) compared to controls. * indicates significant differences compared to cells treated only with IL-1ß ( $p<0.05$ ). \# indicates significant differences compared to untreated cells $(\mathrm{p}<0.05)$. 


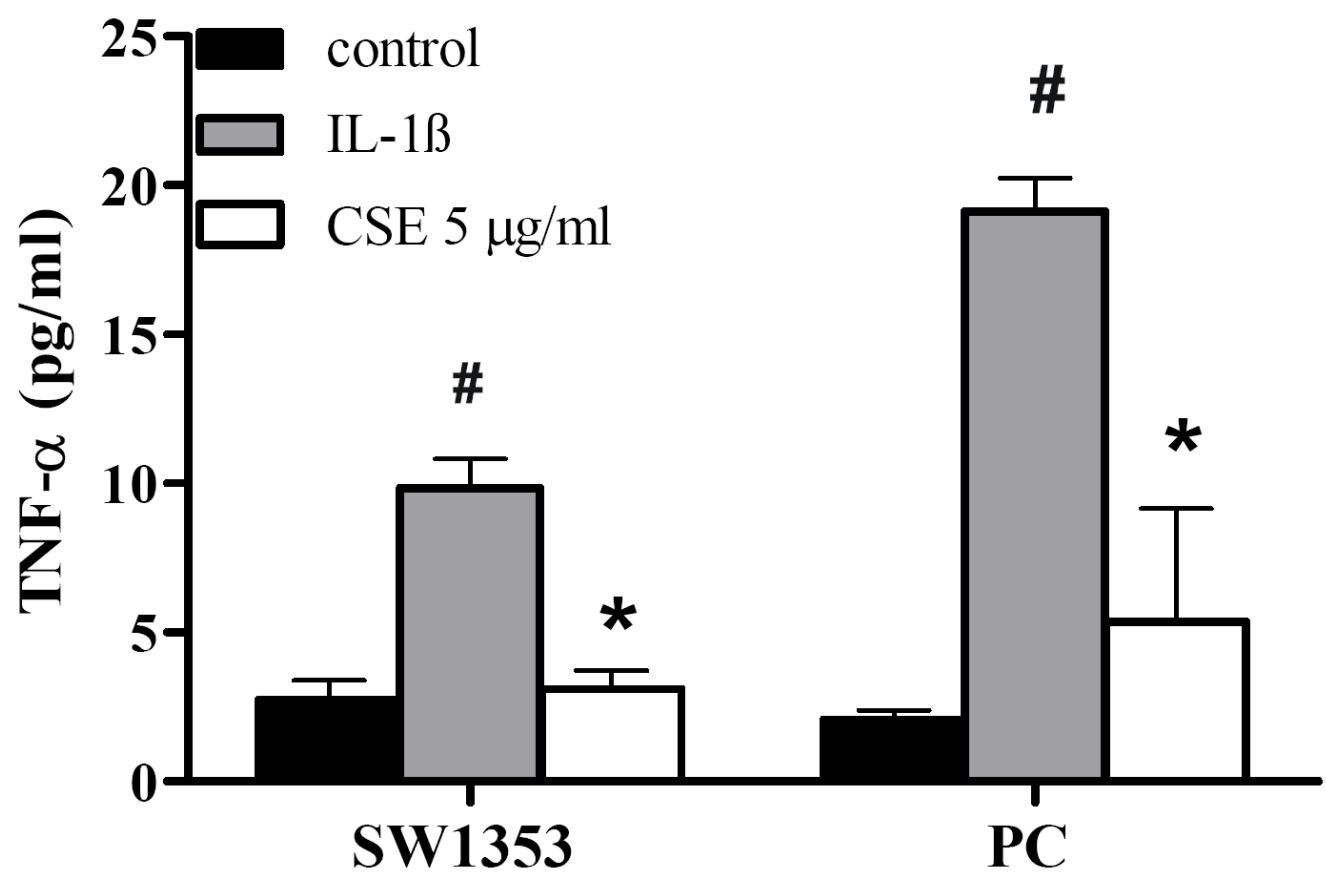

Figure 4. CSE regulates IL-1B-induced TNF- $\alpha$ production in SW1353 and primary chondrocytes After $1 \mathrm{~h}$ preincubation with $5 \mu \mathrm{g} / \mathrm{ml} \mathrm{CSE}$, cells were treated with $10 \mathrm{ng} / \mathrm{ml} \mathrm{IL-1ß}$ for additional $48 \mathrm{~h}$. TNF- $\alpha$ levels in the cell culture medium were analyzed using ELISA assay. Primary cells were isolated from 2 donors and analyzed separately. Data are presented as relative quantities (mean \pm SD) compared to controls. * indicates significant differences compared to cells treated only with IL-1ß $(\mathrm{p}<0.05)$. \# indicates significant differences compared to untreated cells $(\mathrm{p}<0.05)$. 


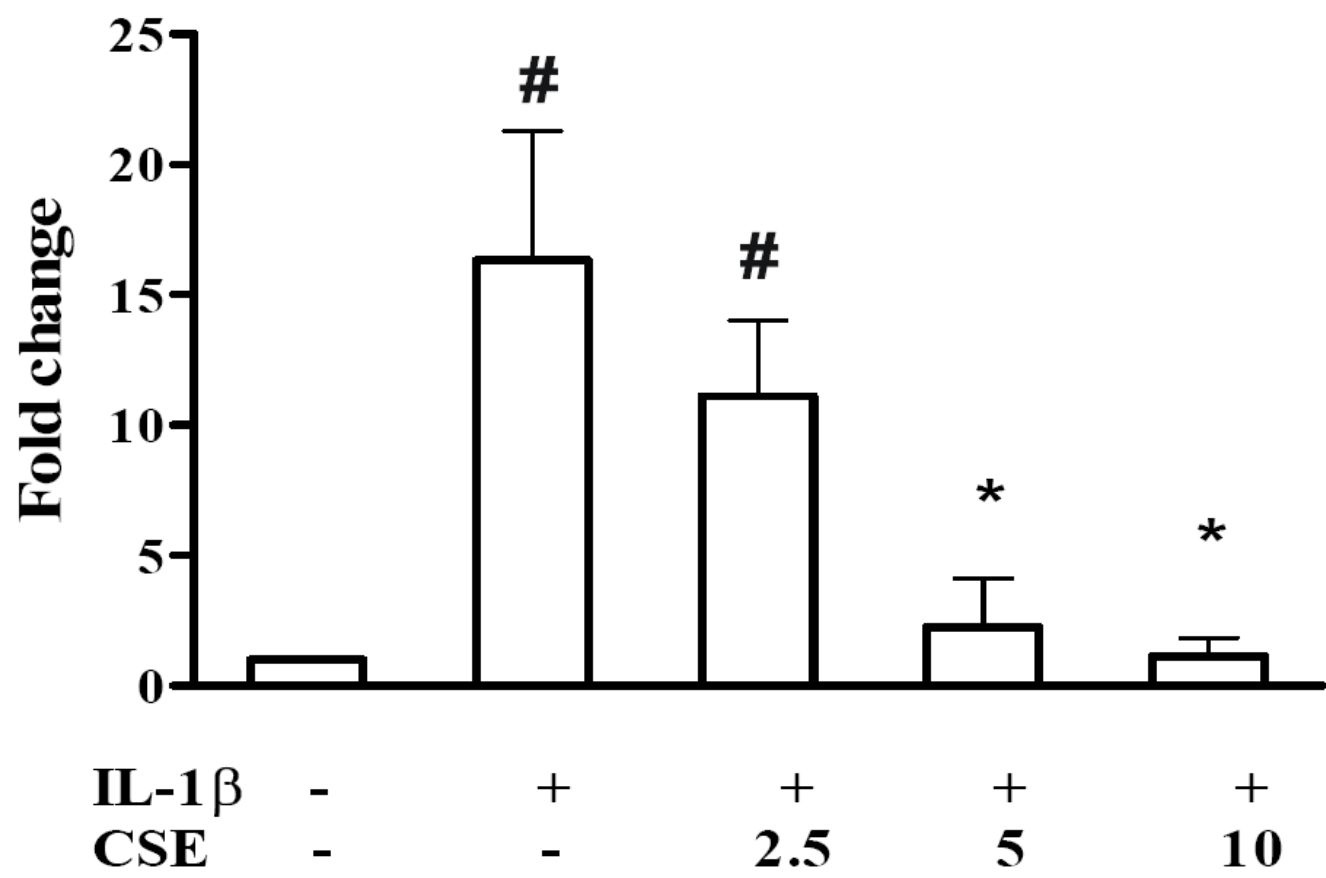

Figure 5. CSE regulates IL-1ß-stimulated NO production in primary chondrocytes Primary cells were isolated from 3 donors and analyzed separately. Cells were incubated with $2.5,5$ and $10 \mu \mathrm{g} / \mathrm{ml} \mathrm{CSE}$ for $1 \mathrm{~h}$ prior to coincubation with $10 \mathrm{ng} / \mathrm{ml} \mathrm{IL-13}$ for $24 \mathrm{~h}$. The nitrite concentration in the culture medium was measured using the Griess assay. Data are presented as relative quantities (mean \pm SD) compared to controls. * indicates significant differences compared to cells treated only with IL-1ß $(\mathrm{p}<0.05)$. \# indicates significant differences compared to untreated cells $(\mathrm{p}<0.05)$. 


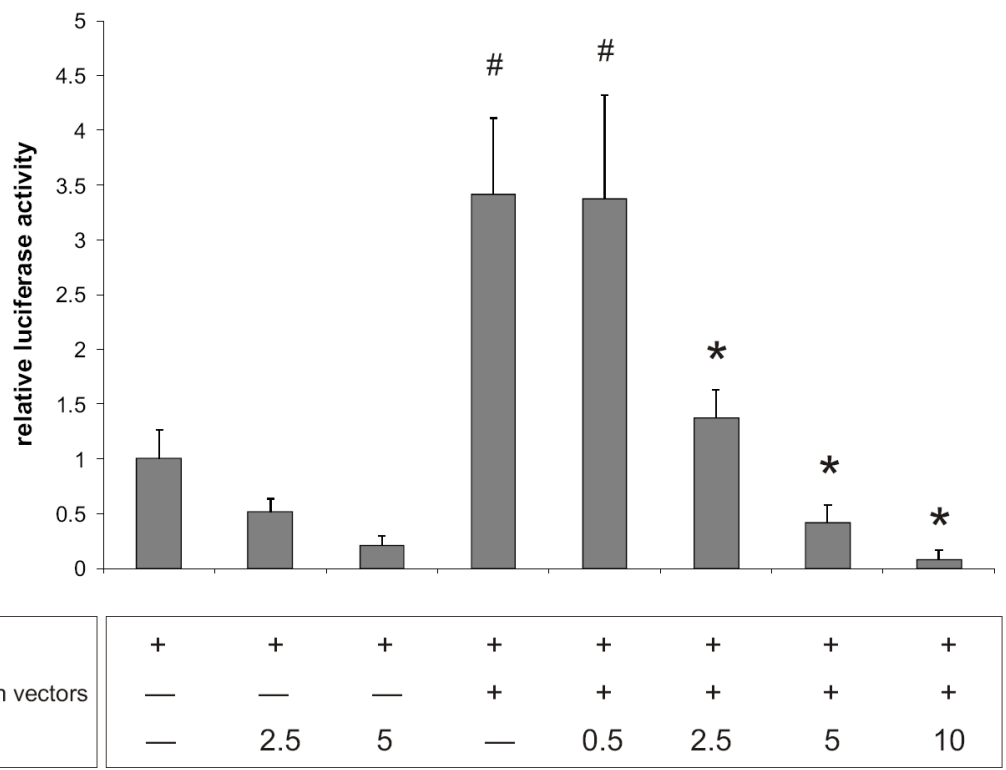

Figure 6. CSE inhibits p65/p50-mediated COX-2 promoter activation in chondrocytes SW1353 chondrocytes were transfected with the pXP2 luciferase construct containing the $-170 /+103$ COX-2 promoter or cotransfected with NF- $\mathrm{BB}$ p50 and p65 expression vectors. Data shown are means of triplicate measurements of luciferase activity from two independent experiments.

\# indicates significant differences with respect to cells transfected with the COX-2 reporter construct and the $\mathrm{pCI}$ empty vector $(\mathrm{p}<0.05)$ * indicates significant differences with respect to cells co-transfected with the COX-2 promoter and the p65/p50 expression vectors $(\mathrm{p}<0.05)$. 


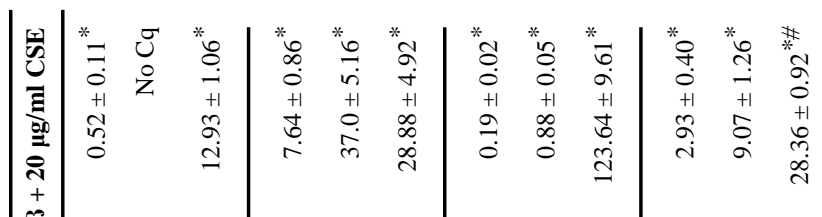

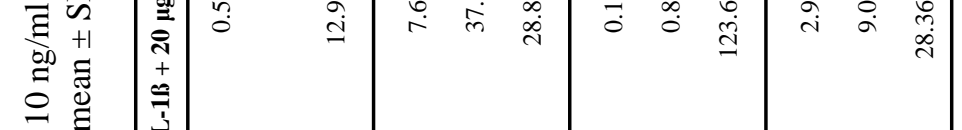

